\title{
ASSESSING ACCOUNTABILITY OF PERFORMANCE MEASUREMENT SYSTEM AND LOCAL GOVERNMENT BUDGETARY MANAGEMENT
}

\author{
Mardiasmo
}

Performance measurement system is an assessment tool, which assesses strategy implementation through financial and non-financial measures. Budget is one of the financial measures used to assess strategy implementation. It is a primary instrument of many function of decision, which is used as a tool to achieve organization goals. Public sector management has to fulfill vertical and horizontal accountability. To have a deeper understanding pertains to performance measurement system and local government budgetary management, this study assessed the existing performance measurement system and local government budgetary management in six municipal/districts. The result showed that the existing performance measurement system is an improper management tool, and that accountability of local government budgetary management is dominated by vertical accountability rather than horizontal accountability. It is suggested that each municipal/district should have its own revenue indicator and saving, increase its cost awareness and health and education sector development budget, implement New Public Management, and reform its responsibility system from vertical accountability to horizontal accountability.

Keywords: accountability; cost awareness; new public management; performance measurement; punish and reward 


\section{Introduction}

This study focuses on the evaluation stage, which includes accountability and some aspects of political involvement. It assesses the usefulness of the existing performance review including the resultant reward and punishment system, and explores the nature of accountability in the local government budgetary management. To achieve these, objectives, the existing performance indicators (PIs) are identified and applied on the income and expenditure sides of budget data obtained from local government's sample.

The evaluation process involves review over annual budget report (Perhitungan $A P B D$ ), which is concerned with the performance of the department/agencies and the whole local government. So, throughout the year, at the end of every quarter, Seksi Pembukuan and Pelaporan compile a quarterly report on the progress of the budget. This forms a basis for current-evaluation.

The annual budget report of the proceeding year is then prepared during the month of May of the new financial year. This forms a basis for post-evaluation. After completion, it is presented to the Local Council for endorsement and then forwarded to the Governor for final approval.

It is the detailed information of quarterly and final reports that are partly utilized to asses the overall performance of agencies or departments and local government as a whole. Reward and punishment are then instituted in a way that reflects the assessed performance.

\section{Theoretical Background}

\section{Performance Review}

The evaluation stage of the budgetary cycle also involves performance re- view, although some authors (e.g. Jakhotiya 1990: 103) argue that, "effective budgeting is a continuous performance evaluation process." Performance review is the same process as performance measurement, therefore PIs are required to ensure successful and accurate evaluation. This includes both internal and external reviews. Internal reviews can have two forms, program evaluation and internal compliance auditing. The first from reviews the efficiency and effectiveness of the agency's programs, while the latter generally concerns with auditing compliance over existing rules and regulations (Nicholls 1991: 253).

The budget characteristics, which relate to the evaluation process, include budgetary control and feed back. Management can use budget any control in three areas. Firstly, it is useful in program planning in order to accommodate the limitations of the organization. Also, it is an official means of resolving conflicts among different parties' interests within the organization. Secondly, budgetary control guarantees the implementation of agreed policies and monitors its success in terms of previously established standards. Finally, management uses budgetary control as a device for motivating, controlling, and evaluating the performance of line managers.

Budgetary feedback requires that the review and discussion of budgetary goals is ongoing continously throughout the year, not only from department managers to their subordinate staff but also from the local government executive level to department managers. With this feedback mechanism in place, all levels of local government staff will not only maintain a clearer vision of the budgetary goals but will also feel a greater sense of cohesion and congruence within the department and level of government. 
Mardiasmo-Assessing Accountability of Performance Measurement System and...

During the last few decades, the new public management approach has been introduced into many private companies and increasingly into the public sector, including local government. This greater emphasis on value for money auditing, which became the new financial orthodoxy of the 1980s, and devolved management led to the increased use of performance measurement as an analytical tool to investigate and demonstrate the value for money offered. It is not surprising that this is the case because many different performance measurement indicators relate quite closely to the different constituents of the value for money formula (Butt and Palmer 1985)

A study by Harris Research Center (1990; quoted in Jackson 1995a: 22) notes that the directors of UK companies still have the tendency to focus internally on financial indicators and ignore external factors such as the perceptions of their customers, their competitors' actions and their companies' relative position to that of their competitors. However, costs can be reduced at the expense of product or service quality and the publics are not always happy with such an outcome. Maximum output at minimum cost is not always satisfactory if the quality of the output, or service is poor. Thus, especially in the public sector, it is important to consider the added dimension of quality or effectiveness. These are known as results indicators.

Other authors, such as Jackson (1995b: 4) suggested other criteria's, for example: excellence, which incorporates the idea of the quality of the service, empowerment (of both employees and consumers), environment and expertise. Carley (1995: 143) defined performance measurement as an attempt to appraise service delivery in a quantitative fashion. In order to do this performance indicators (PIs) are developed. Jones (1995: 122) defines PIs as numerical figures, which can be used in comparison with other figures in order to indicate the relative status of some specific aspect of the performance of the organization.

The main use of PIs is as an instrument of evaluation and change. Without prior agreed PIs, managers might be tempted to use their own subjective judgment in evaluating staff and services and this will result in personal bias entering the equation and, possibly, severe distortions of reality. PIs can neither solve problems nor explain them, but they can pose questions and, on the negative side, indicate areas where change may be needed.

The main problem with the introduction of PIs is the initial suspicion and resistance which they encounter since they are perceived as instruments of control. Their introduction may result in staff losing a sense of vocation and commitment. A further problem occurs when the focus of PIs is narrowed too far. With a narrower focus, it is more likely that an individual or small section will be blamed for any deviance. This produces two problems, first, on the personal front; the staff involved may feel demotivated and subsequently react with hostility to PIs, and second, it may mean that if one person or group can be blamed others would relax and thus the necessary changes may not be implemented (Jones 1995: 124).

Another problem is the number of PIs available. By 1990 there were 2300 contained in the Public Expenditure White Paper (Jackson 1995b: 6). This results in organizations being unsure of which to use, using unsuitable ones or implementing too many and being overwhelmed with information which they are unsure how to use. Implementation of PIs can also take 
considerable time and be a costly experience. Many organizations have abandoned the use of PIs for these reasons. The future of PIs relies on organizations careful selection of relevant PIs and amount of time provided to implement and ajust them.

A further criticism of PIs is that they are, by definition, backward looking. They refer to the past. So, how can they be used effectively to manage future performances? One solution to this is that they should be used in conjunction with scenario planning. The unthinkable should be thought and planned for (Jackson 1995b: 10). If performance measurement is not properly linked to accountability, then a negative impact may be experienced.

In summary, performance review can be rendered useful to the budgetary management not only if the performance measurement is linked to the process of budget accountability but when appropriate PIs are employed as well.

\section{Accountability}

At the evaluation stage, it is also important to examine the concept of accountability and its importance in the budgetary cycle. Mulgan (1997:26) suggested that a distinction must be made between accountability and responsibility. Responsibility is the broader concept regarding "freedom to act, liability for praise or blame, and proper behavior on the part of the person responsible". Accountability is a part of this concept, which defines the responsibility of one person to another. Thus, "accountability and relational responsibility are related as part to whole" (Mulgan 1997: 27). Kearns (1995: 7) described accountability in its most narrow sense as answering to a higher authority, and called it the "compliance-based" notion of accountability. However, the broader concepts of accountability, as discussed below, are what Kearns calls "performance-based." This involves pro-active involvement by local governments in defining the standards by which they are evaluated.

In the last three decades, there have been major changes in the emphasis on factors influencing budgetary control. The 1960s concentrated on financial control and planning. In the 1970s and 1980s, the emphasis was on prioritization in an environment of tax cutting and recession. In the 1990s, however, the emphasis had switched to the concept of accountability (Rubin 1996: 112). As a result of prioritization and cost cutting in the 1970s and 1980s, there was a general distrust and lack of confidence in local governments in terms of their budgetary control. This led to an increase in accountability at local government level. Local governments were forced to improve their accountability to the public in order to restore faith in their actions (Rubin 1996: 114).

Caiden (1978: 540) defined accountability in its most basic sense as the monitoring of expenditure. She stated that budgeting in western countries was characterized partly by high accountability for expenditures and this is important for the raising of revenues from local citizens. Rubin (1996: 115) identified four different concepts of accountability. These include; responding to higher authority (what Devas 1997: 362 calls vertical accountability), reporting to the public, holding elected officials responsible for budget outcomes (this is similar to executive budgeting whereby one chief official is held accountable), and direct citizen control, i.e. the accountability of local government to provide local citizens with the necessary services. 
Mardiasmo-Assessing Accountability of Performance Measurement System and...

In his description of the six aspects of good governance, Blunt (1995: 5) referred to two types of accountability, political and bureaucratic. Political accountability refers to the legitimacy of the individuals holding office. The most popular way of implementing political accountability in the west is by limiting periods of office and holding regular elections (Blunt 1995: 6). Bureaucratic accountability refers to performance monitoring and control. Therefore, it is a different perspective on the concept of accountability discussed in this section. Blunt indicated a need for open systems of public management and transparency, i.e. the necessity to make local government information available to the public. The need for transparency is reiterated in the fifth aspect of good governance, which is the availability and validity of information.

Stewart (1988: 6) emphasized the accountability of local governments to the public. Because the local government is elected by local citizens, it exercises the public power of government and therefore must be accountable to the people it represents. Thus, accountability is linked to the level of participation in the budgetary process by elected individuals, as they are considered to be the representative of the local people. To improve accountability, they must be pro-active rather than passive (Caiden 1978: 541). Accountability to local citizens means that they must be able to understand the budget. In order to achieve this, in recent years efforts has been made to simplify documents outlining budgetary intentions.

Rogers (1990: 18) not only mentioned the concept of public accountability, but also managerial accountability. This is the responsibility of the staff within local governments to their seniors. The staffs are not elected representatives and so those who are elected must hold their actions accountable. Rogers (1990: 19) described this as "a series of reporting relationships" through the staff of local government upwards to elected officials, who then report to the public. Aronson and Schwartz (1996: 164) reinforced this concept by stating that managerial accountability can be enhanced by a performance reporting system.

Accountability (which may take on public and/or managerial roles) can, therefore, be conceptualized as a state of affairs of being tactically and/or strategically responsive to the formal and/or informal demand of relevant information to the bureaucrats, politicians and local citizens. Accountability can thus be vertically or horizontally oriented, be targeted at the politicians, bureaucrats or the public; and internally or externally based. Its degree of influence on the party that is being accountable, however, may depend on the degree of bureaucracy involved.

\section{Methodology}

The evaluation process is not carried out effectively due to laws or guidelines set out by central government. Central governments controlling measures only examine the variance between targets and turn out for both income and expenditure regardless the local government's achievements and efficiency. Furthermore, local government resource allocation is largely prescribed by central and provincial government policy, there is only vertical accountability, i.e. local government is only accountable to central and provincial government.

\section{Case Study}

This study uses a qualitative case study approach with quantitative data. They are useful research method to evaluate 
individual occurrences and phenomena and to provide an explanation of real and actual practices. The subject examined in this study, budgetary cycle (evaluation stage) in Indonesian government, is specific and requires detailed and in-depth analysis. Thus, the study focuses on contemporary phenomenon within a real life context.

As a part of this case study approach, fieldwork was preferred to a survey. Through depth interviews and direct observations, an explanation of local government budget practices was made possible. The evidence from the fieldwork is presented, not just as a single case study, but also as multiple-case studies. These are categorized by area, i.e. each of six local governments, and by unit of analysis, i.e. each of stages of budgetary cycle.

\section{Data Sources}

Primary data, both written and verbal, was collected from sampled local governments. The main methods for the collection of primary data were direct interviews and direct observation. The interviews were conducted with senior staff in the local governments concerned, such as Mayor, the secretary of the local government (Sekwilda), and budget-holders such as, the head of the finance division (Bagian Keuangan), budget sub-division (SubBagian Anggaran), local revenue collection department (Dipenda), and the chief of local development planning board (Bappeda).

Secondary data collection mainly comprised a desk study approach. The major sources for this type of data include national, provincial, and local government laws and regulations concerned with budgeting and performance measurement, annual budget reports and various guidelines issued to local government.

\section{Pilot Study}

The purpose of the pilot study was to provide an overview of financial management in local government. In research, pilot studies are the final preparation for data collection, as it plays a vital role in both the beginning and end of an investigation. After proving an early hypothesis and collecting primary evidences, a pilot study then becomes a tool for modifying the techniques used, which include ways of collecting further data, determining the effectiveness of the next pilot study site based on its convenience, access and geographic proximity, and most importantly, choosing the sort of approach to be used in getting explicit, realistic data from characteristically different sites (Yin 1988). By reviewing each pilot study, an investigator would have the ultimate data collection; both in quantity and quality based on relationships trail basis and the opportunity of seeing matters from different angles.

The pilot study also provided an overview of the relationship among different levels of government: central, province and local. In order to achieve this, semistructured direct interviews, i.e. direct faceto-face interviews were carried out with senior officials, with the budget-holders in provincial and local governments, and with the senior staff at Ministry of Home Affairs and Ministry of Finance.

Due to time constraints, only two different provinces, East Java and South Sulawesi, were selected for conducting an in-depth pilot study. From these two provinces, three local governments were chosen to be investigated, Sidoarjo (East Java), Enrekang and Sidrap (South Sulawesi). Sidoarjo is developed, urban and industrialized, whereas Enrekang and Sidrap are underdeveloped, rural local government and thus would provide a contrast. Sidoarjo was also one of the twenty-six 
Mardiasmo-Assessing Accountability of Performance Measurement System and...

local governments selected by central government in April 1995 to take part in nation-wide experiment in devolved and decentralized local government. Also, these areas largely selected on the basis of convenience. A number of contracts existed in these areas through alumni of Local Government Finance Course (KKD or Kursus Keuangan Daerah), so access to data was easier.

\section{Field Work}

The fieldwork employed a revised version of the topic guide. The first interview was with senior staff at the Directorate General of the MOHA (i.e. Ditjen $P U O D)$, and the Bureau and Directorate General of the MOF (i.e. BAKD and Ditjen Anggaran) in Jakarta. Primarily, this interview, especially with Ditjen PUOD, was held to collect an official letter granting access to local government and permission to carry out this research.

The field research was conducted in six separate local governments whose criteria of selection was based upon three primary indicators, namely; level of local original revenue $(P A D)$, level of economic development and location. These six areas are Banyumas, Bogor, Musi Rawas, Padang, Sidoarjo, and Sidrap (Sidenreng Rappang). The local governments were basically subdivided into two broad categories. The first consists of kotamadya local governments, which are urban, rich and developed (Bogor and Padang). The second group, are kabupaten local governments which are generally rural, poor and underdeveloped (Sidoarjo, Banyumas, Musi Rawas, Sidrap). This second group is further subdivided into pilot areas (daerah percontohan) and other kabupaten local governments. The pilot areas consists of two local governments which are the representatives of the local govern- ments chosen by the Indonesian central government on April 1995 to participate in a nation-wide experiment, in devolved and decentralized local government (Departemen Dalam Negeri 1994, and GOI 1995).

\section{Direct Observation}

A number of different forms of direct observation were undertaken. These ranged from informal observation of budget-holders and their staff at work, to observation of formal meetings. These formal meeting were generally concerned with the budget process but some had a more general nature.

\section{Case Study Analysis and Empirical Findings}

\section{Existing Review of Performance}

The rest of this section focuses more on the performance indicators (PIs). The existing quantitative review of performance is categorized by income PIs, routine expenditure PIs and development expenditure PIs.

\section{Income Performance Indicators}

\section{Income Variance PIs}

Table 1 shows a summary of the existing variance of PIs for both income and expenditure budgets of the sample local governments over a period of five consecutive financial years. The income budget is assessed by the use of realization of $P A D$ (actual $P A D /$ revised $P A D$ ), and realization of local budget or $A P B D$ (actual $A P B D /$ revised $A P B D$ ), which are the subjects of columns A and B respectively in each financial years. Their averages over the period under observation are respectively presented in columns $\mathrm{E}$ and 
Table 1. Existing Income and Expenditure PIs, 1991-1996 (in percentage)

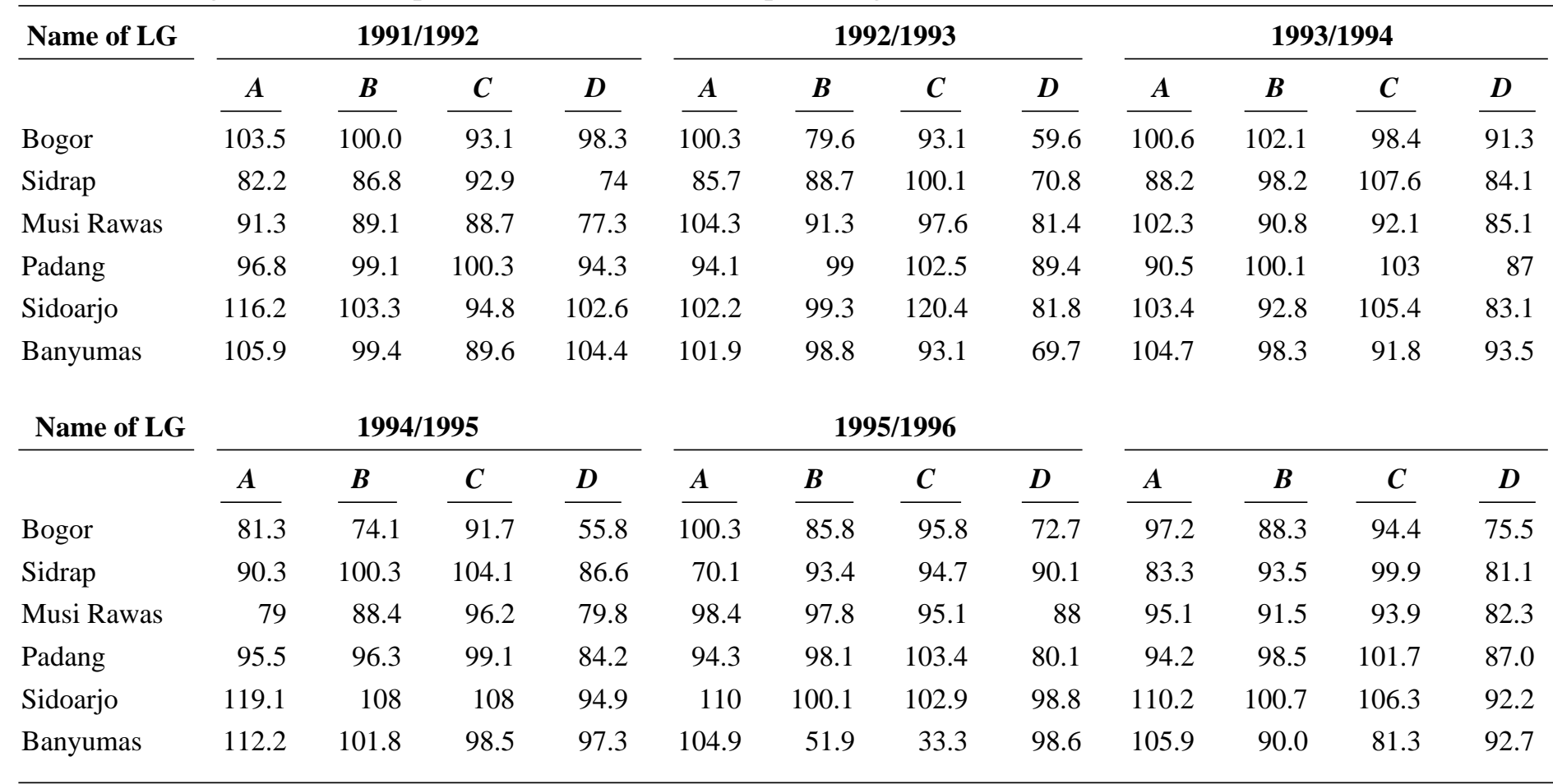

Notes:

$\mathrm{A}=$ Realization of $P A D$ (actual/revised $P A D) ; \mathrm{B}=$ Realization of $A P B D$ (actual/revised $A P B D) ; \mathrm{C}=$ Realization of routine expenditure (actual/revised routine expenditure); $\mathrm{D}=$ Realization of development expenditure (actual/revised development expenditure); $\mathrm{E}=\mathrm{Average}$ realization of $P A D ; \mathrm{F}=$ Average realization of $A P B D ; \mathrm{G}=$ Average realization of routine expenditure; $\mathrm{H}=$ Average realization of development expenditure

Source: Computed from the respective Perhitungan APBD. 
Mardiasmo-Assessing Accountability of Performance Measurement System and...

F. A realization of 100 percent or more is considered a good performance, whilst a realization of less than 100 percent is considered a poor performance.

The average of the $P A D$ indicator reveals that only Banyumas and Sidoarjo local governments have a realization of 100 percent or more. On this basis then, it is only these two that have a good performance on average. Bogor has also managed to keep its realization for all the financial years except 1994/95 when it decreased at 81.3 percent. It is actually this poor performance that affected its average for the period. The performance of the remaining three is generally poor. In particular, Sidrap and Padang have realization levels of less than 100 percent for all financial years. Musi Rawas on the other hand has over 100 percent of realization for only two years (1992/93 and 1993/94).

The $P A D$ indicator then suggests that in general, Sidoarjo, Banyumas and Bogor have a good performance and have effectively implement $P A D$ budget in accordance with the central government's minimum target requirement; whilst Sidrap, Musi Rawas and Padang have a poor performance. The averages of the APBD indicator on the other hand indicate that apart from Sidoarjo, the performance of all the other local governments on the average is poor.
These two indicators can effectively fulfill the minimum target setting objective when they are linked to the reward and punishment system. However, they are misleading since they can be exploited (particularly $P A D$ ) for purposes of setting budgetary slack. But in practice, although the local governments compute these two indicators, only those based on $P A D$ is made use of.

\section{Income Proportion PIs}

This section focuses on how with the aid of PIs the income side of the budget is used to determine the level of local government independence. This is achieved by analyzing $P A D$ as a proportion of $A P B D$, and analyzing the savings indicators. The percentage of $P A D$ as a proportion of $A P B D$ is the indicator that is currently used to assess the capability of local government to generate its own income. It is believed that the higher the ratio, the more capable the local government to become more independent. Since the effectiveness of land and building tax $(P B B)$ income budgeting process now relies solely on the efforts of the local government staff, it renders the existing $P A D$ indicator inadequate. Departemen Keuangan R.I.(1996) suggested that it is more appropriate to include $P B B$ in any indicator that measures their capability to generate income

Table 2. Average Income Proportion PIs for the Sampled Local Governments, 19911996 (in percentage)

\begin{tabular}{|c|c|c|c|c|c|c|c|}
\hline & Bogor & Sidrap & Musi Rawas & Padang & Sidoarjo & Banyumas & Average \\
\hline$\% P A D$ to $A P B D$ & 43.1 & 9.06 & 4.23 & 23.08 & 32.12 & 20.12 & 21.95 \\
\hline$\% P B B$ to $A P B D$ & 5.41 & 14.97 & 28.55 & 5.15 & 17.99 & 8.02 & 13.35 \\
\hline$\% P D S$ to $A P B D$ & 48.51 & 24.03 & 32.78 & 28.23 & 50.11 & 28.14 & 35.30 \\
\hline
\end{tabular}

Source: Computed from the respective Perhitungan APBD 
locally. For instance, this can be achieved by combining it with $P A D$, i.e. $P A D+P B B$ $=P D S$ (own source revenue (OSR)). For illustration purposes, a comparative evaluation of $P A D$ and $P D S$ as indicators is based on the data presented in Table 2 .

The data reveale some variations in $P A D, P B B$ and, therefore, $P D S$ in relation to $A P B D$ across local governments. Three groups can be identified, namely, those generating very low $P A D \mathrm{~s}$ (less than $10 \%$ ) but reasonable $P B B$ s (more than $10 \%$ ), those generating very low $P B B$ s but reasonable $P A D$ s, and those generating both reasonable $P A D$ s and $P B B$ s. The first category includes Sidrap [PAD (9.1\%), PBB (15\%)], and Musi Rawas [PAD (4.2\%), $P B B(28.6 \%)]$. Whilst the second category comprises Bogor [PAD (43.1\%), PBB (5.4\%)], Padang [PAD (23.1\%), PBB (5.2\%)], and Banyumas [PAD (20.1\%), $P B B(8 \%)]$. The third category consists of Sidoarjo [PAD (32.1\%), PBB (18\%)]. The percentage of the $P D S$, however, reveals that only two local governments, Bogor (48.5\%) and Sidoarjo (50.1\%) are at half level. This thus demonstrates that Bogor and Sidoarjo are comparatively independent local governments, whilst the rest, particularly Sidrap (24\%) are relatively dependent, i.e. below the sample average.

Since the respective local governments are attempting to increase their own income and, hence, the percentage share of $P A D$ to $A P B D$, as a consequence, there is competition among local governments in increasing their percentage share of $P A D$ to $A P B D$ on an annual basis. Because of this, they are pursuing a strategy of keeping the growth of the PAD/APBD proportion positive annually. This implies that proportion indicators also have a weakness. I therefore purpose the analysis of the growth of $P A D$ and the growth of $A P B D$, and also the growth of the $P A D /$ $A P B D$ proportion and the growth of the Grant/APBD proportion.

The conclusion that can be drawn from this observation is that when the current indicator, $P A D$ alone is used for income performance review, it tends to penalize the poorer local governments that have a limited local income base. Since the data indicated that the proportion of land and building tax is relatively smaller in the rich local government but relatively larger in the poor local governments, then it is more realistic to use a combination of the two indicators. On this basis then, own source revenue $(P D S)$ may be a better alternative indicator. However, growth has a disadvantage because it only reflects the change in trend. For instance, a very high growth rate followed by a slightly smaller growth will reflect a negative change in the trend. This can be misleading and such growth and proportion should be used concurrently.

The alternative method that is currently being used to assess the capability of independence is the use of local governments' savings indicator. It is used to asses their capability to save funds and use them for development purposes and, therefore, the capability to develop independently. In a way then, the savings indicator reflects a local government capability to attain independence or autonomy.

Savings or Tabungan Pemerintah Daerah (which in this sense is actually current surplus) can be referred to as own source revenue $(P D S)$ minus non-staff routine expenditure (NRE). Non-staff routine expenditure is in turn defined as total routine expenditure (RE) minus subsidies from central and provincial governments. This 
Mardiasmo-Assessing Accountability of Performance Measurement System and...

is because almost all of the staff costs are funded by these subsidies. Simply the most generally adopted formula is:

Savings $=(P A D+$ Sharing tax and non-tax) - NRE

Savings is a weak indicator when computed as a ratio of the $A P B D$. For instance, since the definition involves nonstaff routine expenditure, there is a tendency for some local governments to increase their savings by shifting some activities from routine expenditure to development expenditure. In order to overcome this temptation, I propose that an indicator of savings as a proportion of development expenditure budget should be implied. This indicator is also capable of assessing the capacity of the savings to finance development expenditure and equally reflects the strength of the respective local governments in attaining autonomy.

Furthermore, I view that the local government contribution to development expenditure can be further emphasized by refining the definition of development expenditure from 'total development expenditure (DE)' to 'total original development expenditure (ODE)'. ODE is defined as DE less contributions from central and provincial governments. This is justified by the fact that central and provincial governments do not always provide 100 percent finance for its projects.

Table 3 presents the savings indicator as a percentage of $A P B D, \mathrm{DE}$ and ODE, as an average for the 1991/92 1995/96 financial years and its respective growths. If a high percentage is taken to represent good savings, then the figures for proportion of savings to $A P B D$ are self-evident with Sidoarjo scoring highest and Banyumas lowest. However, as explained above, this indicator should be used with caution and needs to be supplemented by the growth of the proportion indicator. When this is done, it reveals that the growth of Sidoarjo, which had the highest proportion, has reduced; while Banyumas, which had the lowest proportion, has been growing.

The proportion of savings to development expenditure shows that the rank of the local governments more or less remain the same as that of the proportion of savings to $A P B D$ indicator. However, when it is supplemented by the growth of its proportion, it provides a different meaning. This time, the proportion is growing for all the local governments except Bogor. On the other hand, this indicates that Sidrap and Banyumas are capable of financing more that 100 percent of their total original development expenditure from sav-

Table 3. The Average Existing and Proposed Savings PIs for the Sampled Local Governments 1991-1996 (in percentage)

\begin{tabular}{|c|c|c|c|c|c|c|c|}
\hline & Bogor & Sidrap & M. Rawas & Padang & Sidoarjo & Banyumas & Average \\
\hline A. Savings as $\%$ of $A P B D$ & 19.6 & 11.4 & 19.4 & 10.4 & 26.2 & 9.3 & 16.1 \\
\hline B. Savings as $\%$ of DE & 44.7 & 33.4 & 38.4 & 37.2 & 47.5 & 17.9 & 36.5 \\
\hline C. Savings as $\%$ of ODE & 92.4 & 100.4 & 97.4 & 89.2 & 98.5 & 120.3 & 99.7 \\
\hline Growth A & 1.7 & 18.4 & 1.5 & 15.03 & 4.5 & 10.8 & 8.7 \\
\hline Growth B & -1.9 & 20.2 & 3.4 & 19.7 & 9.3 & 15.9 & 11.1 \\
\hline Growth C & -7.5 & 8.0 & 5.2 & 5.6 & 2.7 & 2.7 & 2.8 \\
\hline
\end{tabular}

Source: Computed from the respective Perhitungan APBD 
ings. The growth rate of the proportion is similar in direction to those of the development expenditure indicator discussed above.

Once more, the results indicate that the use of the $A P B D$ and development expenditure indicators, which have a component from the central and provincial governments, tend to penalize poor local governments with a poor local income base. Consequently, they do not reflect the actual real potential internal growth of the local government.

\section{Routine Expenditure Performance Indicators}

\section{Routine Expenditure Variance PIs}

Routine expenditure is currently evaluated by the use of realization of routine expenditure (actual routine expenditure/revised routine expenditure). A realization of less or equal to 100 percent reflects a good performance, while a realization of more than 100 percent reflects a poor performance. This indicator and its average are presented in columns $\mathrm{C}$ and $\mathrm{G}$ of Table 1 , for each of the financial years respectively.

The averages for routine expenditure indicate that with the exception of Padang and Sidoarjo, all the local governments have been effective in meeting the maximum target requirement. Individual timeseries observation reveals that Bogor, Musi Rawas, and Banyumas have consistently had a realization of less than 100 percent. Sidrap, on the other hand was effective in only two of the years (1991/92 and 1995/ 96), while Padang and Sidoarjo were effective in only one of the years, 1994/95 and, respectively, 1991/92. According to this indicator then, only Bogor, Musi Rawas and Banyumas have attained a good performance.

In summary, only three of the sampled local governments have adhered to the central government requirement of a maximum setting. But this maximum indicator is rather crude and unrealistic. For instance, a realization of over 100 percent for any local government reflects poor performance. But surely any local government getting a realization of, say 100.5 percent, should in principal have a better performance than that whose realization is, say 50 percent or even 70 percent. Probably it would be more realistic to add some degree of tolerance.

\section{Routine Expenditure Proportion PIs}

This section analyses how PIs, that is computed from the routine expenditures side, can be used to evaluate the degree of local government cost awareness. ${ }^{1}$ In order to evaluate the degree of cost awareness, a detailed systematic analysis is required. First, a definition of 'miscellaneous expenditure' is required, followed by the computation of its proportion to routine expenditure for all the local governments.

The budget of Indonesian local governments' routine expenditure is classified under ten items as indicated in Table 4. However, each local government's department/agency routine expenditure is subdivided into only five components, namely: staff cost, material or equipment expenditure, repair and maintenance expenditure, traveling expenditure, and other expenditure. Seven of the local governments' ten categories are clearly defined but three of them, namely; 'other expendi-

\footnotetext{
${ }^{1}$ Cost awareness can be defined as the capability to minimise expenditure, particularly on the miscellaneous component of routine expenditure. In other words, it is the efficiency of expenditure management.
} 
Mardiasmo-Assessing Accountability of Performance Measurement System and...

ture,' 'unclassified expenditure' or expenditure not included elsewhere, and 'unpredicted expenditure' or contingencies, are rather ambiguous. These three items combined together will be referred to as 'miscellaneous expenditure' here after. A smaller proportion of 'miscellaneous expenditure' to total routine expenditure reflects a higher degree of cost awareness.

Since routine expenditure is funded by both internally generated income and externally generated income, the distribution of a local government routine expen- diture can be judged better when the subsidies are disregarded. This removal of the subsidy from routine expenditure gives what will be referred to as non-staff routine expenditure (NRE). In other words, the computation of non-staff routine expenditure is not only because the staff costs mostly come from the subsidy but also because there is a need to evaluate the local government expenditure from its internal financial resources.

A large expenditure on 'miscellaneous expenditure' means a proportionally small expenditure on the other items

Table 4. The Proportion (\%) of Actual Routine Expenditures (RE) of all Indonesian Local Governments 1991-1996

\begin{tabular}{|c|c|c|c|c|c|c|}
\hline Kind of Routine Expenditure & $1991 / 92$ & $1992 / 93$ & $1993 / 94$ & $1994 / 95$ & $1995 / 96$ & Average \\
\hline 1. Staff costs & 65.61 & 64.82 & 68.71 & 65.94 & 64.55 & 65.93 \\
\hline 2. Material expenditure & 12.22 & 11.72 & 10.52 & 11.23 & 12.29 & 11.60 \\
\hline 3. Repair \& Main. Expenditure & 3.55 & 3.37 & 3.06 & 3.18 & 3.12 & 3.26 \\
\hline 4. Official travel expenditure & 1.81 & 1.94 & 1.85 & 1.91 & 1.97 & 1.90 \\
\hline 5. Other expenditure & 10.52 & 10.64 & 10.03 & 10.7 & 11.32 & 10.64 \\
\hline 6. Repayment on loan and interest & 1.00 & 1.02 & 0.87 & 1.54 & 1.22 & 1.13 \\
\hline 7. Compensation/subsidies & 1.46 & 1.88 & 1.76 & 1.85 & 1.85 & 1.76 \\
\hline 8. Pension and aid expenditure & 0.13 & 0.37 & 0.01 & 0.02 & 0.01 & 0.11 \\
\hline 9. Unclassified expenditure & 3.25 & 3.30 & 2.67 & 3.03 & 3.18 & 3.09 \\
\hline 10. Unpredicted expenditure & 0.45 & 0.94 & 0.52 & 0.60 & 0.49 & 0.60 \\
\hline Miscellaneous expenditure & 14.22 & 14.88 & 13.22 & 14.33 & 14.99 & 14.33 \\
\hline
\end{tabular}

Source: Computed from the Biro Pusat Statistik, Jakarta

Table 5. Other, Unclassified, Unpredicted, and Miscellaneous Expenditure As a Proportion of Total Non-staff Routine Expenditure (NRE) 1991-1996 (in percentage)

\begin{tabular}{|c|c|c|c|c|c|c|c|}
\hline & Bogor & Sidrap & M. Rawas & Padang & Sidoarjo & Banyumas & Average \\
\hline Other exp. as \% of NRE & 48.04 & 25.92 & 22.59 & 32.46 & 26.71 & 29.44 & 30.86 \\
\hline Unclassified exp. as \% of NRE & 15.88 & 10.20 & 23.48 & 6.24 & 23.87 & 2.89 & 13.76 \\
\hline Unpredicted exp. as \% of NRE & 0.09 & 0.16 & 0.97 & 1.82 & 0.32 & 0.25 & 0.60 \\
\hline Misc. exp. as \% of NRE & 64.01 & 36.28 & 47.04 & 40.52 & 50.90 & 32.58 & 45.22 \\
\hline
\end{tabular}

Source: Computed from the respective Perhitungan APBD 
Gadjah Mada International Journal of Business, September 2002, Vol. 4, No. 3

Table 6. The Setwilda's NRE Percentage Distribution for Bogor, Sidrap, and Banyumas 1993-1996 (in percentage)

\begin{tabular}{|c|c|c|c|c|c|c|c|c|c|c|c|c|}
\hline & \multicolumn{3}{|c|}{ 93/94 } & \multicolumn{3}{|c|}{$94 / 95$} & \multicolumn{3}{|c|}{$95 / 96$} & \multicolumn{3}{|c|}{ Average } \\
\hline & Bogor & Sidrap & $\underline{B}$ 'mas & Bogor & Sidrap & B'mas & Bogor & Sidrap & $\underline{B^{\prime} m a s}$ & Bogor & Sidrap & $\underline{\text { B'mas }}$ \\
\hline Material exp. & 54.32 & 50.86 & 62.95 & 61.23 & 61.88 & 54.57 & 61.26 & 53.53 & 51.02 & 58.94 & 55.42 & 56.18 \\
\hline $\mathrm{R} \& \mathrm{M}$ exp. & 13.28 & 20.26 & 10.32 & 11.03 & 15.99 & 9.78 & 12.05 & 12.77 & 7.57 & 12.12 & 16.34 & 9.22 \\
\hline Trav. Exp. & 1.21 & 8.24 & 8.5 & 1.16 & 6.38 & 7.11 & 0.77 & 11.87 & 6.34 & 1.05 & 8.83 & 7.32 \\
\hline Other exp. & 31.19 & 20.64 & 18.23 & 26.58 & 15.75 & 28.54 & 25.92 & 21.83 & 35.07 & 27.89 & 19.41 & 27.28 \\
\hline
\end{tabular}

Note: B'mas is Banyumas

Source: Computed from the respective Perhitungan APBD

(including materials and repair \& maintenance). Expenditure on materials, repair, and maintenance particularly reflect how well the services are being looked after and how far the assets of the local government are being preserved. Based on table 5 , this then means that local governments of Bogor, Sidoarjo and Musi Rawas are putting very little emphasis on their services or future service delivery. Hence, there is a strong case for the need to shift funds from 'miscellaneous expenditure' to the materials and repair and maintenance of services.

The Secretariat of local government is evidently the most dominant agency with an average share of about 45.5 percent. As can be further analyzed from Table 6 for Bogor, Sidrap and Banyumas, the Secretariat's non-staff routine expenditure is divided further into material, repair and maintenance expenses, traveling costs and other expenditures.

The figures for these local governments show that on average, material expense takes the dominant share followed by 'other expenditure', repair and maintenance expenses and lastly by traveling costs. The average of 'other expenditure' is 27.9 percent for Bogor, 27.3 percent for
Banyumas and 19.4 percent for Sidrap. This analysis clearly demonstrates that when analysis of miscellaneous expenditure is made while excluding the sumbangan component (non-staff routine expenditure), it reveals that cost awareness is lacking in the local governments particularly in the Secretariat.

\section{Development Expenditure Performance Indicators}

\section{Development Expenditure Variance PIs}

Under the current system, the development expenditure is assessed by the use of realization of development expenditure (actual development expenditure/revised development expenditure). As has already been discussed under routine expenditure, a realization of less or equal to 100 percent reflects a good performance and vice versa. This indicator and its average are respectively presented for each of the financial years in columns D and H of Table 1 .

The averages for the development expenditure indicators suggest that all the sampled local governments have been effective in implementing the central government's maximum target requirement. This is confirmed by the individual 
Mardiasmo-Assessing Accountability of Performance Measurement System and...

time-series local government indicators, which demonstrated that apart from Sidoarjo (1991/92) and Banyumas (1991/ 92), all the realization rates for all the local governments are less than 100 percent for the entire period under observation. According to this method of assessment, all the sampled local government qualifies for good performance under the development expenditure indicator. But once more, as has been discussed under routine expenditure variance PIs, this indicator is rather crude and unrealistic, and used only occasionally.

\section{Development Expenditure Proportion PIs}

In this section, I propose development expenditure proportion PIs that can be used to assess the sectoral allocation of development funds. This section, therefore, attempts to asses whether the system employed by central government in apportioning local government development funds is in line with the local government priorities.

A brief analysis of the trends of the sectoral shares shows that on average the transport sector has accounted for at least one third of the development expenditure for Sidrap. This includes for example the construction of new and the enlargement of old roads that are under the responsibility of the local governments. However, expenditure on local development, and health and social welfare has been falling. Needless to say, the expenditure on state apparatus has been growing from a mere 6.7 percent in 1991/92 to almost one quarter of the development expenditure (22\%) in $1995 / 96$. Once more, this is an indicator of the 'state' placing its interests before those of the local citizens and consequently 'grabbing' a significant share of the funds at the expense of the local citizens.

Similarly, the transport sector has dominated the share of Padang's development expenditure account for over one third and at times close to one half. The data however, show a declining trend. The shares of the education and health sectors have also been decreasing over time. Expenditure on local development is on the other hand improving, while the state apparatus share though showing a declining trend has always accounted for at least 15 percent of the total development expenditure.

Between 1991/92 and 1993/94 the transportation sector in Sidoarjo accounted for 40 percent, 31 percent and 27 percent of the development budget in the respective years. However, this dropped to almost one half in 1994/95 and 1995/96, i.e. 17 percent and 20 percent respectively. The education sector which accounted for the second largest share between 1991/92 and 1993/94 (22\%, 27\%, and 23\%), however, dropped to the fourth position after being displaced by dwelling and residence, and state apparatus and control sectors. The most prominent upward trend is that of the state apparatus sector whose share of 13 percent in 1991/92 and 1992/93 has put it into third position, and has since increased to 25 percent. Consequently, it currently holds the leading share. The health sector's share has followed a downward trend from 9 percent in 1991/92 to 4 percent in 1995/96.

In Banyumas, the transportation sector is once more dominant. It responsibles for over one third of the total development expenditure budget, but it has experienced a consistently declining trend. The education sector takes the second largest share, but this also has been on the decline, i.e. from 25 percent in 1991/92 to 16 percent in $1995 / 96$. The health sector which accounted for the third largest share in 1991/ 92 has displaced to seventh position by the 
dwelling and residence, and state apparatus and control whose shares have grown over time; and the local development and environment sector.

The transportation sector is unmistakably the dominant sector in Musi Rawas' development expenditure, accounted for over 40 percent in all years except 1993/94 and 1994/95, when its share dropped to 34 percent and 36 percent respectively. State apparatus has held a second position with the share of 19 percent, except in 1995/96 when the share dropped to 13 percent and was displaced by the education sector (which was originally third in ranking) and the local development sector (which was originally fourth in ranking). The health sector's share has been on a decline and is currently worryingly small (i.e. $2.6 \%$ ).

Bogor's development expenditure budget has been dominated by the local development sector during the last three financial years under observation. For instance, it held almost one half of the total budget in 1995/96 financial years. This is followed by the transportation sector whose share has consistently been declining. In third position is the state apparatus sector, whose share has inconsistent pattern. The education sector has experienced a very substantial decline from 33 percent in 1991/ 92 to a mere 5 percent in 1995/96. The share of the health sector remains small and decreases continously.

The brief analyses given above demonstrate that in all cases (except Musi Rawas' education sector) the health and education sectors have experienced a downward sectoral share trend. Moreover, the share of the health sector is very small and does not count among the top four sectors in all cases. Similarly, the education sector's share is only second in Musi Rawas and Banyumas, but since its trend is declining, then it will very soon become insignificant as well. This is inappropriate because human resources development is very essential for the economic development of any region. Its importance should, therefore, be reflected in the development budget.

All this are resulted from a misunderstanding or lack of co-ordination between the local governments and the central government. Whereas the central government is of the view that the strength of a local government is indicated by the number of functions, the local governments are of the view that it is not the number, but properness of the function that matters. The central government is apparently interested in 'numbers' for political reasons. For instance, there is a tendency for the public sectors in Indonesia to act as 'social agencies'. But this can be a political maneuver meant to boost the membership or support the ruling party.

In summary, the analysis has demonstrated the weaknesses of the central government's apportionment of the local government development funds. For instance, there is lack of local government development expenditure budget prioritization brought about by central government's imposition of uniform sector classification, and cross-local government uniform sector weighted. Further, over expenditure in the state apparatus sector and, hence, the pursuance of policies in the interests of the ruling party has meant that the development expenditure budget does not support the needs of the local governments and has thus rendered it ineffective.

\section{Reward and Punishment System}

To have an effective evaluation process, some form of reward and punishment system is needed. As there is no standard system in place at local govern- 
Mardiasmo-Assessing Accountability of Performance Measurement System and...

ment level in Indonesia, each local government employs its own system. For example, if the head of local revenue collection department and his department reach their income target, they are all eligible for a number of rewards.

The interview with the head of local revenue collection department of Padang revealed another reward system which works on the same basis but is geared towards other employees is that offered to the village headmen (Kepala Desa) within the sub-districts (kecamatan). In this mechanism the village headmen manage to collect all the money from each of their villages and when the sub-local government reaches its target by the end of the calendar year (end of December) that sublocal government is entitled to receive back 50 percent of the collected money. It may spend the money on its facilities for the sub-local government and the villages within it. However, they are entitled to only 30 percent if the money is collected by the end of January, 20 percent if it is collected by the end of February, and 10 percent if it is collected by the end of March. However, if they do not reach their income target, there are numbers of punishments. This include losing the headmanship job. If local government performs poorly in general, then the main punishment is given and, particularly with respect to the land and building tax, a black flag is raised outside the Mayor's office.

In addition, there is a system of rewards and punishments linked to the interim evaluation process. These again vary among local governments, but the main system is fairly standard. For instance, the interview with the head of local revenue collection department of Musi Rawas revealed that if the head of a department notices that an employee has performed very well in the preceding quarter, then rewards in form of days off and financial payments can be offered. When the head sends the employee out into the field to collect taxes and income, an authorization letter pays a stipend to him for traveling $(S P J)$ based on how long (how quickly) it takes for him to collect a certain amount of money. Such a reward has a positive effect on the tax collection of the forthcoming years since it acts, as a 'promotion' exercise in its own right.

The foregoing discussion indicates that the existing reward and punishment system focuses mainly on the income side of the budget. The review presents that traditional budget approach is more popular in developing countries. It is based on central government control. Thus, local governments follow instructions imposed by central government. For instance, there is maximum target for expenditure and a minimum target for income. Its weakness is that it focuses on the input with the logic being that if the local governments do not spend to the maximum target then their service provision to the local communities is poor or vice-versa.

Because of this weakness, the New Public Management approach is suggested as a better alternative. This is because like the private sector, local governments are treated as profit centers. Since there is devolved budgeting, local governments have discretion in decision making. This approach focuses more on the output and is therefore more responsive to issues such as effectiveness, efficiency and accountability of financial resources. Under this approach, there is even a possibility of setting up a reward and punishment system based on the expenditure component of the budget by incorporating expenditure indicators capable of reflecting the utilization of resources. 


\section{Nature of Accountability}

The nature of accountability can be linked to the cost awareness concept discussed in the previous section. To achieve this, the components of Table 5 are analyzed individually to find out where the non-specified routine expenditure, particularly that under 'other' and 'unclassified' components, are mostly spent. If the most significant proportion goes to the improvement of the local citizens' services, then it is consistent with an emphasis on horizontal accountability. However, the converse suggests an emphasis on vertical accountability.

Table 7 illustrates the Secretariat of local government's other expenditure percentage distribution for Banyumas, Bogor, Musi Rawas, and Sidrap. In Sidrap, on average guest expenses holds the dominant share $(43.9 \%)$ followed by operational expenses (40.3\%); and similarly, in
Bogor, guest expenses dominates (34.2\%) followed by operational expenses (33.9\%). However, in Banyumas operational expenses is dominant followed by employee's welfare $(16.7 \%)$ while in Musi Rawas operational expenses is dominant followed by guest expenses (30.8\%).

It is worth noting that some of the items included in 'other expenditure' more appropriately fall under different items. Among these include for example employees' welfare and incentive expenses, which fit under 'staff costs'; and transportation costs which fits under 'official travel expenditure'. The dominant operational and guest expenses are mostly with respect to officials from the central and provincial government levels. For example, when budgeting assistants from the provincial governments visit the local governments. This clearly shows a vertical orientation.

Table 7. The Several Setwilda's 'Other Expenditure' Average Percentage Distribution for Banyumas, Bogor, Musi Rawas and Sidrap 1992-96 (in percentage)

\begin{tabular}{|c|c|c|c|c|c|}
\hline Type of Expenditures & Banyumas & Bogor & Musi Rawas & Sidrap & Average \\
\hline Operational expenses & 53.1 & 33.9 & 33.2 & 40.3 & 40.1 \\
\hline Employees' welfare & 16.7 & 18.6 & 12.6 & 6.7 & 13.7 \\
\hline Guest expenses & 13.2 & 34.2 & 30.8 & 43.9 & 30.5 \\
\hline
\end{tabular}

Note: Guest expenses are for all the departments or agencies

Source: Computed from the respective Perhitungan APBD

Table 8. Unclassified Expenditure' Average Percentage Distribution for Bogor, Sidrap, Banyumas and Musi Rawas 1992-1996 (in percentage)

\begin{tabular}{|c|c|c|c|c|c|}
\hline Type of Expenditure & Bogor & Sidrap & Banyumas & Musi Rawas & Average \\
\hline Donations to Vertical Agencies & 30.0 & 21.2 & 30.0 & 30.4 & 27.9 \\
\hline Donations to Political Parties & 1.5 & 14.5 & 19.5 & 2.6 & 9.5 \\
\hline Donations to Professional Associations & 68.5 & 47.2 & 39.0 & 23.9 & 44.7 \\
\hline Donations to Social Organizations & 0.0 & 16.9 & 0.6 & 43.1 & 20.2 \\
\hline Donations to Tourism Activity & 0.0 & $\mathrm{n} / \mathrm{a}$ & $\mathrm{n} / \mathrm{a}$ & 0.0 & $\mathrm{n} / \mathrm{a}$ \\
\hline
\end{tabular}

Note: $\mathrm{n} / \mathrm{a}$ - not applicable

Source: Computed from the respective Perhitungan APBD 
Mardiasmo-Assessing Accountability of Performance Measurement System and...

The figures of 'unclassified expenditure' average percentage distribution for Bogor, Sidrap, Banyumas and Musi Rawas are presented in Table 8 . They show that in Banyumas this component is dominated by donations to Professional Associations (39\%) followed by donations to Vertical Agencies (30\%) and then donations to Political Parties (19.5\%).

Similarly, in Sidrap and Bogor, it is dominated by donations to Professional Associations (respectively $47.2 \%$ and $68.5 \%$ ) followed by donations to Vertical Agencies (respectively $21.2 \%$ and $30 \%$ ). However, the figures for Musi Rawas reveal the dominance of donation to Social Organizations (43.1\%) followed by donations to Vertical Agencies (30.4\%) and then donations to Professional Associations $(23.9 \%)$. This adds evidence to the attention vertical agencies receive. Moreover, donations to Political Parties can also be treated as vertical in orientation. On the other hand, the Social Organizations, which directly impact the local community receive comparatively insignificant donations, except for Musi Rawas.

In addition, an example from Bogor also illustrates the lack of prioritizing its local needs. In 1996/1997, Bogor revised its expenditure on primary education from Rp25 millions to Rp45 millions. However, it eventually spent only the original Rp25 million. When asked what caused this shortage, the answer was that the budgeted extra of Rp20 millions had been diverted and donated to a local football club (Persatuan Sepakbola Bogor/PSB) as a method of showing appreciation for its good performance.

The main source of this problem seems to arise from the local government's dependency on central and provincial governments. Much as there was an initial move to pursue a decentralization policy, the administrative system in Indonesia has practiced all the three policies, i.e. decentralization, deconcentration and co-administration.

This issue is also partly attributed to the desire and hence the struggle for power. For instance, the central government (ruling party) may want to continue exercising political influence (power) at the local government level. In order to achieve this, a member of the Armed Forces $(A B R I)$ is often appointed as Mayor. The Mayor then becomes both a political and 'financial' (because of corruption) power. Since he has both access and influence to the higher authorities, the local government officials have no choice but to become generous to him and his superiors, and equally wait for favors in return.

The main reason why the armed forces are of strategic importance is because it is the source of political power. Any political party that has no strong links with the armed forces, therefore, has no power whatsoever. The armed forces which has the function of defense and social order (dual function or $d w i$-fungsi) is hence a strategic organ to make an alliance with. One way of buying this alliance (from the ruling party's point of view) is by appointing strategic army figures to offices such as that of Mayor. By doing so, however, the central government eventually ends up using the local government as a tool to promote its interests.

The local government, therefore, finds itself in a vicious circle. For instance, it is dependent upon the central and provincial governments. Because of this, the central and provincial governments impose leaders upon it, and as a consequence these leaders have to show 'loyalty' through generous donations, in hope for returned favors. The end result is that the local government will continuously be depen- 
dent upon the central and provincial governments.

In summary, most of the non-staff routine expenditure is targeted by the Secretariat, which spends a high proportion of it on entertaining guests and prestigious activities rather than the development of the social welfare of the local citizens. This suggests that a high percentage of the funds are not being directed to where they are supposed to go, i.e. to the improvement of the social welfare of the local community. Rather, they are being directed to where control is concentrated, i.e. central and provincial government for political activities; and to activities, which can lead to prestige. Evidently, the local government tends to incline its accountability towards the central and provincial governments rather than towards the local citizens for whom it is directly responsible. For instance, many basic elements of horizontal accountability such as transparent auditing, public accounts committee style reports, and debate in the media are missing. These findings are in line with those observed by Barker (1982), Rubin (1996), and Devas (1997).

\section{Concluding Remarks}

The objective of this study is to proof that the current performance measurement system is an inappropriate management tool, and that the accountability of the local government budgetary management is dominated by vertical accountability at the expense of horizontal accountability.

Several PIs were applied to case study data and comparatively evaluated. Under the variance PIs, it was revealed that the income budget of the performance measurement system is currently assessed by the use of $P A D$ and realization of local budget, while the expenditure budget of the performance measurement system is assessed by the use of 'realization' of routine expenditure, and 'realization' of development expenditure. However, when applied to the case study, it became evident that the income indicators of the performance measurement system are misleading and exploitable.

The percentage of $P A D$ as a proportion of local budget $(A P B D)$ is the indicator that it is currently used by the central government to access the capability of local governments to generate own income. Application of the indicators on data from sampled local governments suggested that the $P A D$ proportion indicator tends to penalize the poorer local governments that have a poorer internal income base. As a consequence, $P D S$ (proportion and growth of proportion) was judged as a better alternative indicator to capture the local government performance in generating own income.

The local government savings indicator is used to asses their capabilities to save funds and use them for development expenditure purposes. That is, it reflects the capability for the local government to attain autonomy. This indicator encourages the local governments to generate more income on one hand, and to control expenditure, particularly routine expenditure, on the other.

Cost awareness in the Indonesia's local governments is rather limited, mainly because they tend to incline their accountability towards the central and provincial government at the expense of accountability to the local citizens. This lack of cost awareness is indicated by the routine expenditure proportion indicators when applied on miscellaneous expenditure.

Analysis of the apportionment of the development expenditure budget demonstrated that in almost all the cases with the 
Mardiasmo-Assessing Accountability of Performance Measurement System and...

exception of the transportation sector, all the other important sectors such as education and health account for small individual, shares in the Indonesia's local governments. To make matters worse, the trend of their shares has been declining. Blatantly, most of the existing PIs are inappropriate to be used as tools of evaluating the local government budgetary management. Further, the existing nature of accountability is more inclined to the higher-level governments and weak towards local communities.

The nature of accountability should, therefore, be reversed and made more horizontal and less vertical than it currently is. This can be attained by giving genuine autonomy to local governments that achieve decentralized status. Such decentralization should give them real authority and, hence, more discretion in the management of their resources. If such au- tonomy is granted, then the significance of the Local Council in decision-making process will be boosted. Since the Local Council has the capacity to be more responsive to the local citizens, it is hoped that they will similarly be more accountable to them, hence, increasing horizontal accountability and reducing vertical accountability. Needless to say, this requires more open and free flow of information and communication between the local government officials and the local citizens. This will eventually give positive impact on local government budgetary management. To achieve this, there is a need for a more transparent, realistic and less bureaucratic central-local government financial relations. Above all, the central and provincial government need to reduce the intervention in the local government budgetary management.

\section{References}

Aronson, J. R., and E. Schwartz, E. (eds.). 1996. Management Policies in Local Government Finance. Washington D. C.: The International City Management Association.

Barker, A. 1982. Governmental bodies and the networks of mutual accountability. In Barker (ed.). Quangos in Britain. London: Macmillan: 3-33.

Kantor Statistik dan Bappeda Banyumas. 1996. Kabupaten Banyumas Dalam Angka 1995. Jawa Tengan: Banyumas.

Biro Pusat Statistik 1994. Financial Statistics of The Second Level Local Government 1991/1992 - 1992/1993. Indonesia: Jakarta.

1997. Financial Statistics of The Second Level Local Government 1994/1995 1995/1996. Indonesia: Jakarta.

Blunt, P. 1995. Cultural relativism, good governance and sustainable human development. Public Administration and Development 15: 1-9.

Kantor Statistik dan Bappeda Bogor Bogor. 1996. Kabupaten Bogor Dalam Angka 1995. Indonesia: Bogor. 
Butt, H., and B. Palmer. 1985. Value for Money in the Public Sector: The Decision Makers' Guide. Oxford: Basil Blackwell.

Caiden, N. 1978. Patterns of budgeting. Public Administration Review (November/ December): 539-544.

Carley, M. 1995. Beyond performance measurement in a professional public service. In Jackson, P. M. (ed.). Measures for Success in the Public Sector: 143-148. (First published in Public Money \& Management 8 (4). 1988). London: CIPFA.

Departemen Dalam Negeri R.I. 1994. Kepmendagri No. 105/1994 tentang Pelaksanaan Projek Percontohan Otonomi Daerah pada Kabupaten/Kotamadya Dati II. Jakarta.

Departemen Keuangan R.I. 1996. Monitoring Indicators of Repelita VI, Urban Policy Action Plan, Implementation Results, Main Text. Municipal Finance Project, Bureau for Regional Financial Analysis (in cooperation with Bappenas, Ministry of Home Affairs and Ministry of Public Works). Jakarta.

Devas, N. 1997. Indonesia: What do we mean by decentralization? Public Administration and Development 17: 351-367.

GOI. 1995. Peraturan Pemerintah No. 8/1995 tentang Penyerahan Sebagian Urusan Pemerintahan Kepada 26 (dua puluh enam) Dati II Percontohan. Jakarta.

Jackson, P. M. 1995a. Public service performance evaluation: A strategic perspective. In Jackson, P. M. (ed.). Measures for Success in Public Sector: 19-26 [First Ed. published in 1993 in Public Money and Management 13 (4)]. London: CIPFA.

1995b. 'Introduction: Reflections on Performance Measurement in Public Service Organizations', in Jackson, P. M. (ed.), Measures for Success in the Public Sector, London: CIPFA, 1-18.

Jakhotiya, G. P. 1990. Budgeting and Budgetary Control. New Delhi: McGraw-Hill.

Jones, B. M. 1995. Local Government Financial Management. Hertfordshire: ICSA Publishing.

Kearns, K. P. 1995. Accountability and entrepreneurial public management: The case of the orange county investment fund. Public Budgeting \& Finance (Fall): 3-21.

Mulgan, R. 1997. The processes of public accountability. Australian Journal of Public Administration 56 (1): 25-36.

Musi Rawas. 1996. Kabupaten Musi Rawas Dalam Angka 1995. Kerjasama Kantor Statistik dan Bappeda, Lubuk Linggau, Sumatra Selatan.

Nicholls, D. 1991. Managing State Finance. Sydney: The NSW Treasury.

Padang. 1996. Kabupaten Padang Dalam Angka 1995. Kerjasama Kantor Statistik dan Bappeda, Padang, Sumatra Barat.

Rogers, S. 1990. Performance Management in Local Government. Harlow, Essex: Longman Group UK Ltd. 
Mardiasmo-Assessing Accountability of Performance Measurement System and...

Rubin, I. S. 1996. Budgeting for accountability: Municipal budgeting for the 1990s. Public Budgeting \& Finance (Summer): 112-132.

Sidenreng Rappang. 1996. Kabupaten Sidenreng Rappang Dalam Angka 1995. Kerjasama Kantor Statistik dan Bappeda, Pangkajane, Sulawesi Selatan.

Stewart, J. 1988. Understanding the Management of Local Government: Its Special Purposes, Conditions and Tasks. Longman Group UK Ltd.

Sidoarjo. 1996. Kabupaten Sidoarjo Dalam Angka 1995. Kerjasama Kantor Statistik dan Bappeda, Sidoarjo, Jawa Timur.

Yin R.K. 1988. Case Study Research: Design and Methods (Revised Ed.) applied Social Research Methods Series (Vol. 5). London: Sage Publications. 